\title{
CHANGING CONSTITUTIONAL IDENTITY: CONSTITUTIONAL REFORM AND NEW CONCEPT OF HUMAN RIGHTS IN GEORGIA
}

\author{
Dimitry Gegenava \\ Sulkhan-Saba Orbeliani University
}

\begin{abstract}
Constitutional reform of 2017 - 2018 amended the whole text of Georgian basic law, including the $2^{\text {nd }}$ chapter - Basic Human Rights. Many articles and human rights were displaced to other chapters as general principles, some new and postmodern rights were added to the text. These changes are not only ordinary amendments; they make constitutional court and other state organs to realize their duties, and individuals to find new ways of protection of their rights. New constitutional regulation raises new forms and meanings, but this novation includes risks and perils, that should be discussed and analysed not only in the light of national constitutional law, but also in comparative and international context. This article describes main directions of amendments in the chapter on human rights and analyses perspectives, positive and negative aspects of them.
\end{abstract}

Keywords: Constitution, Georgia, Constitutional Reform, Human Rights, Constitutional Identity

\section{INTRODUCTION}

Every constitutional amendment is a challenge for new democracies. Unstable political regime and unfinished constitutional order, so characterising these countries, needs great patience and energy to be sustainable and face them. This is impossible without collaboration of all political actors.

Constitution of Georgia was adopted in $1995 .{ }^{1}$ Despite numerous constitutional amendments during past 22 years, ${ }^{2}$ articles in the $2^{\text {nd }}$ chapter, which includes provisions on human rights, were amended only several times. Constitutional reform of 2017 - 2018 amended the whole text of Georgian basic law, ${ }^{3}$ including the $2^{\text {nd }}$ chapter. Many articles and human rights were displaced to other chapters as general principles, some new and postmodern rights were added to the text.

These changes are not only ordinary amendments; they make constitutional court and other state organs to realize their duties, and individuals to find new ways of protection of their rights. New constitutional regulation raises new forms and meanings, but this novation includes risks and perils, that should be discussed and analysed not only in the light of national constitutional law, but also in comparative and international context.

See BABECK, W. Elaboration and Adoption of the Constitution in Georgia (1993 - 1995). Tbilisi: Iris, 2013.

GEGENAVA, D. Retrospection of the Constitutional Reforms of Georgia: In Search of the Holy Grail, In South Caucasus Law Journal, No. 8 (2017), p. 238.

3 See Constitutional Law on "Amending Constitution of Georgia", 13 October 2017; Constitutional Law on "Amending Constitutional Law on Amending Constitution of Georgia", 23 March 2018. 


\section{GEORGIAN CONSTITUTIONAL IDENTITY, HUMAN RIGHTS AND NEW CHALLENGES OF DEMOCRACY}

Protection of human rights is not a result, but the on-going process. Constitutional concept of human rights is critical for the society, state and individuals. This concept should be sustainable but the same time flexible for better implementation and realization of human rights in practice. Core of each nation's constitutional identity is made with concept of its state construction and human rights, ${ }^{4}$ especially with the rights, binding public power and creating basic frames for state actions. Therefore changing constitutional regulation on human rights can override the whole system of constitutional thought, develop or ruin it.

Georgia developed European, German model of human rights and declared human dignity as the basis of the whole system. ${ }^{5}$ Constitutional court defined it as the main idea of the state and linked all other rights to that. ${ }^{6}$ The Court made many famous and revolutionary decisions interpreting Article 17 of the constitution of Georgia. It seems, that human dignity is the basic part of Georgian constitutional identity and this is not only for academic purposes but also inspired with the spirit of nation.

Constitutional reform of 2017 - 2018 renewed even structure of the basic law, so it automatically changed human rights chapter too. $2^{\text {nd }}$ chapter of the constitution begun with citizenship, equality and right to life. ${ }^{7}$ This order was illogic, these norm were just regular progression of rights and norms. Now new redaction of the Georgian Constitution starts with the article 9 that guarantees inviolability of human dignity. New place ${ }^{8}$ in the constitution is adequate and emphasizes attitude of our legal system concerning the human rights. Beginning of the chapter declares priority and the meaning of human dignity as the legal basis of all human rights.

\section{SUBJECTIVE AND OBJECTIVE RIGHTS}

Constitutional reform of 2017 - 2018 aimed to modify whole concept of regulation of human rights in the basic law. Constitutional Commission differed subjective and objective understanding of human rights and decided to remove declarative norms to the chapter on general principles. ${ }^{9}$ Subjective rights are connected to individuals or legal entities and basing on them it is possible to file the case to constitutional court ${ }^{10}$ remained in the $2^{\text {nd }}$ chapter. Such kind of rights are very useful, because they are practical and everyone can refer to them, they are concrete and don't declare abstract ideas.

4 JACOBSOHN, G. J. Constitutional Identity. Harvard University Press, 2010, p. 153.

5 Commentary to the Constitution of Georgia, Chapter 2, Citizenship, Basic Rights and Freedoms. Edited by P. Turava, Tbilisi, 2013, p. 107.

6 See TUGHUSHI, T., BURJANADZE, G., MSHVENIERADZE, G., GOTSIRIDZE, G., MENABDE, V., Human Rights and Case-Law of the Constitutional Court of Georgia. Tbilisi, 2013.

7 Articles 12, 13, 14 of the Constitution of Georgia (24.08. 1995 Redaction).

8 Starting with human dignity was receipted from Germany but unlike it, where the basic law starts from this right, in the constitution of Georgia it got place in the beginning of the human rights' chapters, which is structurally better. See: Basic Law of the Federal Republic of Germany, 23 May 1949, Art.1(1).

9 Institute for Development of Freedom of Information, Assessment of the Proposed Constitutional Amendments, 27 April 2017; available at: <https://idfi.ge/en/evaluation_of_proposed_actions_as_part_of_georgias_constitution_project> [10/08/2018]

10 e.g. Right to Property, Right to Fair Trial and etc. 
Objective rights have declarative meaning and are abstract, in this point of view, they are more general norms and principles, and they can't be implemented directly. ${ }^{11}$ Beside this, objective rights are very important, they help judges or other officials to understand real meaning of rights, interpret true idea of norms by teleological or system interpretations.

Constitutional commission decided to structure new chapter using only subjective rights and take any other to the general principles or remove from the constitution. ${ }^{12}$ And this was principally right position, because it is very important to have "useful" provisions in the chapter, which is the basis of protection of your rights; ${ }^{13}$ these norms are the legal ground to submit your case to the court and demand from the state to act according its responsibility. ${ }^{14}$ It would work in ideal world, but in practice constitutional court needs objective rights to refer them when there is a difficult case, or when judges need basics according positive law for argumentation. Beside commission's logic some of objective rights are still in the $2^{\text {nd }}$ chapter and its illogic. There are two explanations: 1 . Commission couldn't differ these two types of rights; 2 . Removing some rights, even they have objective meaning, would be unpopular, ${ }^{15}$ so parliament and politicians decided to forget about principal position and remain some of those rights in the chapter.

Some abstract rights that moved in the first chapter and set in socio-economical goals and principles of Article 4 became privilege for citizens, while subjective rights in the $2^{\text {nd }}$ chapter of the constitution are applicable for everyone. ${ }^{16}$

Article 28 (Right to Healthcare), Article 29 (Rights to Protect the Environment), or Article 30 (Right to Marry) still cannot be the legal basis for constitutional claim and they are still abstract and hypothetic. But they are very popular and no one wanted to rescue their authority and popularity removing them from the text. Unfortunately, their formulations are not useful. They are more like principles than real basic rights. It would be better to achieve the primary goals of constitutional commission and make $2^{\text {nd }}$ chapter with subjective rights, which have not only declarative meaning, but can be implemented in the process of realization of human and civil rights.

\section{SOME MODERN AND POST MODERN RIGHTS}

Modernity and development always get new ideas and concept of human rights and freedoms. Some of them are just concretized versions of existing rights, but there is a need to emphasize something for the higher level of guarantee.

New article 17 of Georgian Constitution provides freedom of access and use the internet - of course it is a part of freedom of thought and freedom expression. But for new generation and mod-

11 JOWELL, J. Review of Amendments to the Constitution of Georgia in Respect of Human Rights and Judiciary Matters. March 2017, p. 5.

12 Institute for Development of Freedom of Information, Assessment of the Proposed Constitutional Amendments, 27 April 2017; available at: <https://idfi.ge/en/evaluation_of_proposed_actions_as_part_of_georgias_constitution_project> [10/08/2018]

13 Ibid.

14 Ibid.

15 Differing these rights and what to leave in the chapters was political question. See JOWELL, J. Review of Amendments to the Constitution of Georgia in Respect of Human Rights and Judiciary Matters. March 2017, p. 5.

16 Ibid, p. 6. 
ern society internet became not only an important thing but irreplaceable part of everyday life, many people express their ideas in social media, blogs and use internet sources to implement their freedom. Legal experts and international organizations positively marked such novation. ${ }^{17}$

Civil Law system differs from Anglo-American Law and all of these differences firstly come from dividing law as private and public. ${ }^{18}$ European system recognizes this division and includes administrative law. In practice it is a law of executive branch of government, strictly connected to the public governance. ${ }^{19}$ Any individual or legal entity needs to be secured and protected from the interruption of administrative organs. Beside the litigation we have case hearings by administrative organs and they can make their own decisions..$^{20}$ These decisions can be appealed at courts, but it is very important to have constitutionally guaranteed right for fair hearing on the administrative level too. Amendments created special norm, which provides the right to give a fair hearing of case by an administrative body within a reasonable period of time. ${ }^{21}$ This article automatically made possibility for protection rights by constitutional litigation.

Right to education was in the basic law but amendment changed it formulation and added a new concept for institutional independence, which is vital for academic entities. ${ }^{22}$ New article 27 gives individual and collective understanding of right to education. It guarantees freedom to choose education for any person and autonomy of a higher educational institution for organizations.

Unfortunately, amendments changed standard of the access public information and widened the scope of restriction and "substantially worsened the opportunities for accessing such information". ${ }^{23}$ "Protecting interests of legal proceedings" is very wide legitimate aim and it will be very problematic to define whether it is necessary in the democratic society. This provision gives public authority opportunity to interpret some situations on behalf their position and they can restrict access to the public information, which may be dangerous for the government.

New redaction of the constitution guaranteed independence of the public broadcaster and declared its independence from public of commercial influence. ${ }^{24}$ The constitution also provides special status, "institutional and financial independence of the national regulatory body - established to protect media pluralism and the exercise of freedom of expression in mass media, prevent the monopolisation of mass media or means of dissemination of information, and protect the rights of consumers and entrepreneurs in the field of broadcasting and electronic communications". 25

17 Ibid.

18 See FERNANDO, O. Conceptual Differences between the Civil Law System and the Common Law System. In Southwestern University Law Review. Vol.19, 1990, p. 1164.

19 KÜNNECKE, M. Tradition and Change in Administrative Law. An Anglo-German Comparison. Berlin: Springer, 2007, p. $3-4$.

20 See General Administrative Code of Georgia, 25 June 1999.

21 Constitution of Georgia, 24 August 1995, Art.18. (Shall become effective upon taking of the oath of office by the President of Georgia to be elected in the next Presidential Elections)

22 Ibid., Art.27.

23 Opinion on the Draft Constitutional Amendments Adopted on 15 December 2017 at the Second Reading by Parliament of Georgia, Adopted by the Venice Commission, CDL-AD(2018)005, Venice, 16 - 17 March 2018, Par.33.

24 Constitution of Georgia, 24 August 1995, Art.17 (6). (Shall become effective upon taking of the oath of office by the President of Georgia to be elected in the next Presidential Elections)

25 Ibid., Art.17 (7). 


\section{PROPERTY AND OWNERSHIP - SPECIAL PROTECTION OF AGRICULTURAL LAND}

In June 2012 Constitutional Court of Georgia declared some provisions of regulations on agricultural land unconstitutional. Law on Agricultural Lands prohibited to own such kinds of lands to foreigners and legal entities registered outside of Georgia. The constitutional court annulled this regulation. The decision evoked heterogeneous reactions in population. New parliament and government that were elected after a few months from the judgment were against of it. Parliament adopted new law and declared moratorium on selling agricultural lands to foreigners, but the court annulled this moratorium too.

According the constitutional parliament has no right to adopt any law with the concept that was declared unconstitutional by the constitutional court. The only way is to incorporate this rule in the basic law. So the parliament decided to act this way. New article 19 on right to ownership includes provision regarding property right on agricultural land. Basic Law recognized agricultural land as a resource of special significance and provided that it may only be in the ownership of the State, a self-government unit, a citizen of Georgia, or an association of the citizens of Georgia. Exceptional cases may be determined by the organic law, which shall be adopted by a majority of no less than two thirds of the total number of members of Parliament. The mandatory quorum is unusual for organic laws, but because of significance and the will of Georgian population, parliament decided to make more guarantees for stability.

Stability is very important, but it should not be in controversy to investment climate and country's financial sustainability. "Such a provision of course has a political as well as legal dimension. It is well known that foreign investment is often deterred by countries which do not permit land ownership to non-nationals." ${ }^{26}$ Results will be shown only after implementation of new rules.

Some constitutions contain intellectual property provisions with general norms of property, but new redaction of Georgian basic law chose another way: freedom of artistic and intellectual creativity is set in new article $18 .^{27}$ Such norm was also in the former redaction too and this underlines the position of the country regarding intellectual property and copyright, which is very important and popular problem of XXI century.

\section{FREEDOM OF BELIEF, RELIGION AND CONSCIENCE}

Freedom of belief and religion is one of the most sensitive rights in law. Current redaction of Georgian constitution guarantees freedom of belief and religion and explicitly gives only one possibility to interrupt in it. This freedom can be restricted unless expression thereof infringes on the rights of others.

After constitutional amendments ways of restriction increased. After enforcing the amendments, restriction of such rights shall be admissible in accordance with law for the purposes of ensuring

26 JOWELL, J. Review of Amendments to the Constitution of Georgia in Respect of Human Rights and Judiciary Matters. March 2017, p. 13.

27 Ibid. 
public safety, or for the protection of health or the rights of others, insofar as is necessary in a democratic society. These reasons were receipted from the European Convention on Human Rights, which was adopted more about 60 years ago and has broader mechanisms of interruption in the secured sphere of freedom of belief and religion. Step by step European Court of Human Rights narrowed it and restricted the ways of interruption of right. In $21^{\text {st }}$ century it's unbelievable to use the old regulation and implement it, when you have much higher level of protection.

Following recommendation of the Venice Commission, parliament of Georgia changed formulation of restriction of these rights and "national security", "preventing crime" and "administering justice" "which are not legitimate aims in the sense of the second paragraph of Article 9 ECHR have been deleted". ${ }^{28}$ Now legitimate grounds for restriction are "public safety" and "protection of health or the rights of others", this formulation is much better. Restoring the old norm, which guarantied more protection and more stability in the multi religious society, should amend this provision in the constitution.

\section{MARRIAGE}

Definition of marriage in the constitution was changed and narrowed. Constitution of 1995 declared that marriage is based on equality of rights and the free will of spouses. This provision was taken from the first Georgian constitution of 1921. In the twenties of last century Social Democrats, ruling party at that time, made extraordinary and unusual concept of marriage for the first quarter of the $\mathrm{XX}$ century - Equal rights and free will of spouses. ${ }^{29}$

Last constitutional reform changes this declaration and added terms in the provision. Now it sounds: Marriage, as a union of a man and a woman for the purposes of building a family, shall be based on equality of rights and the free will of spouses. Now it is a classic definition from the civil $\operatorname{code}^{30}$ and it is not clear why it is included in the basic law of Georgia. Unfortunately some political parties used this topic for political purposes, anti European rhetoric and provided the whole parliamentary campaign to make such amendments to the constitution. ${ }^{31}$

New constitutional norm is in compliance with ECHR provision ${ }^{32}$ - "Men and women of marriageable age have the right to marry and found a family, according to the national law governing the exercise of that right". ${ }^{33}$ New case law of the European Court of Human Rights doesn't obligate states to make possibility for marriage of homosexuals, but if there is an alternative for of partnership for heterosexual couples, it recommends granting equivalent to same-sex couples too. ${ }^{34}$

28 Opinion on the Draft Constitutional Amendments Adopted on 15 December 2017 at the Second Reading by Parliament of Georgia, Adopted by the Venice Commission, CDL-AD(2018)005, Venice, 16 - 17 March 2018, Par.30.

29 Constitution of the Democratic Republic of Georgia, 21 February 1921, Art. 40 (1).

30 See Civil Code of Georgia, 26 June 1997, Art. 1106.

31 Institute for Development of Freedom of Information, Assessment of the Proposed Constitutional Amendments, 27 April 2017; available at: <https://idfi.ge/en/evaluation_of_proposed_actions_as_part_of_georgias_constitution_project> [10/08/2018]

32 JOWELL, J. Review of Amendments to the Constitution of Georgia in Respect of Human Rights and Judiciary Matters. March 2017, p. 17.

33 ECHR, Art. 12.

34 See Vallianatos and Others v. Greece. [ECtHR], App. nos. 29381/09 and 32684/09, 7 November 2013; JOWELL, J. Review of Amendments to the Constitution of Georgia in Respect of Human Rights and Judiciary Matters. March 2017, p. 13. 
Venice Commission gave recommendation to the Georgian parliament and underlined in the opinion, that Article 30 "should in no case be interpreted as prohibiting same-sex partnerships". ${ }^{35}$

New definition of marriage was incorporated in the constitution for political goals and it doesn't have any connection to the protection of human rights. ${ }^{36}$ This definition was already in the legislation of Georgia. Adding such provisions reduces the meaning of Constitution and it becomes just ordinary law that regulates everyday questions. These provisions should be excluded from the basic law; there is no place for narrow legal definitions and ordinary law questions in the most important document of the state.

\section{ARTICLE 39 - DISPLACED NORM}

Before the constitutional reform, Article 39 provided: "The Constitution of Georgia shall not deny other universally recognized rights, freedoms and guarantees of an individual and a citizen that are not expressly referred to herein but stem inherently from the principles of the Constitution". This norm came from the first constitution of the Democratic Republic of Georgia. ${ }^{37}$ But this was receipted from the ninth amendment of the US constitution. ${ }^{38}$ Real goal of existing such norms in the constitutions is to secure human rights, because it's impossible to enumerate all of them in the basic law. ${ }^{39}$

The ninth amendment of the US constitution is some kind of "penumbral" norm ${ }^{40}$ and gives a wide opportunity for judicial interpretation. ${ }^{41}$ Some constitutional commentators think, this amendment includes the idea of limitation of government by natural rights to secure possibility of protection other rights in first eight amendments. ${ }^{42}$ Article 39 has the same function and its place in the $2^{\text {nd }}$ chapter of the Georgian constitution is not accidental, it is directly linked to the material and procedural mechanisms of protection of human rights, set in the legislation.

Constitutional Court of Georgia defines, that Article 39 includes rights, which indirectly, but still comes from the constitutional principles and this can be interpreted as some kind of regulation. ${ }^{43}$ The only standard of interpretation of this article is the constitution and constitutional principles.

35 Opinion on the Draft Revised Constitution Adopted by the Parliament of Georgia at the Second Reading on 23 June 2017, Adopted by the Venice Commission, CDL-AD (2017) 023, Venice, 6 - 7 October 2017, Par. 38.

36 Institute for Development of Freedom of Information, Assessment of the Proposed Constitutional Amendments, 27 April 2017; available at: <https://idfi.ge/en/evaluation_of_proposed_actions_as_part_of_georgias_constitution_project> [10/08/2018]

37 Constitution of the Democratic Republic of Georgia, 21 February 1921, Art. 45.

38 PUTKARADZE, N. Human Rights in the Constitution of 21 February of 1921. In Beginnings of Georgian Constitutionalism - 90 Years of the Constitution of 1921. Batumi, 2011, p. 58.

39 See GEGENAVA, D., JAVAKHISHVILI, P. Article 39 of the Constitution of Georgia: Internally Displaced Norm Pending the Shelter and the Phenomenon of Fear of the Unknown in Georgian Constitutionalism. In Academic Herald, Special Edition, 2017.

40 See: HART, H.L.A. Concept of Law. Clarendon Law Series, 1997.

41 LENY, L.W. Origins of the Bill of Rights. New Haven, London : Yale University Press, 2001, p. 242.

42 MCAFFEE, T.B., BYBEE, J.S., BRYANT, A.C. Powers Reserved for the People and the States: A History of the Ninth and Tenth Amendments. A Reference Guide to the United States Constitution. Westport, Connecticut, London : Praeger Publishers 2006, p. 38; LENY, L.W. Origins of the Bill of Rights. New Haven, London : Yale University Press, 2001 , p. 254.

43 Recording Notice \#2/2/416 of the Constitutional Court of Georgia on "Public Defender of Georgia v. Parliament of Georgia”, 29 May 2007, III, 1. 
Interpreting Article 39, the constitutional court constituted many important and relevant standards and principles, ${ }^{44}$ and this norm became one of the last chances for the claimants, on which they could file cases to the court.

Explanatory note from the parliament of Georgia interprets this "movement" of norm as ordinary case and suggests constitutional court to interpret general principles widely. ${ }^{45}$ Its quiet unusual, first of all, parliament has no right to suggest any way of interpretation and implementation to the constitutional court, secondly, the court declared many times, that claimant can only use provisions of the second chapter for the legal ground of claims. ${ }^{46}$ So currently Article 39 becomes non useful for protection of rights and will be general principle, just sounding perfect.

\section{CONCLUSION}

These changes are not only ordinary amendments; they make constitutional court and other state organs to realize their duties, and individuals to find new ways of protection of their rights. New constitutional regulation raises new forms and meanings, but this novation includes risks and perils, that should be discussed and analysed not only in the light of national constitutional law, but also in comparative and international context.

Dynamic development of human rights is the basic for democracy and the rule of law. Constitutional experience of developed countries shows that formation of constitutional identity is strictly linked to the concept of basic rights, its scopes and the limitation of government, which is essential for every nation. Qualified system of human rights doesn't mean there is no place or necessity for future development, concretization or even creation of new ideas, new rights. Constitutional basis for rights is the signal from the system of values, constitutional understanding helps the whole system to reanalyse main concepts.

Georgian constitutional identity is still in the process of formation and we even can't see the final destination. Ongoing constitutional reform has made many interesting amendments, re-establish classic institutions in the new form. Definitely there are problems too, its irreplaceable pars of reform. In any case every reform must be necessary for nation and national development, good direction can reinforce margins and understanding of Georgia's mission in the world, or opposite, it can ruin even those thin fundaments, which is so tricky and overrule destinations that has already been passed.

\section{Bibliography:}

BABECK, W. Elaboration and Adoption of the Constitution in Georgia (1993 - 1995), $2^{\text {nd }}$ Ed. Tbilisi : Iris, 2013.

Commentary to the Constitution of Georgia, Chapter 2, Citizenship, Basic Rights and Freedoms, Edited by P. Turava, Tbilisi, 2013.

44 ZOIDZE, B. Constitutional Control and Order of Values in Georgia. Tbilisi, 2007, p. 157.

45 Explanatory Note on the Draft Constitutional Law on "Amendment to the Constitution of Georgia"; available at: <http:// constitution.parliament.ge/uploads/masalebi/2. 05. konstitucia-barati.pdf> [06. 07. 2018]

46 See e.g. Judgment \#1/7/727 of the Constitutional Court of Georgia on "Citizen of Georgia Giorgi Sekhniashvili v. Parliament of Georgia", 21 April 2017, II, 2; Judgment \#1/9/664 of the Constitutional Court of Georgia on "Non-Profitmaking Organization “Open Circle of Georgia” v. Parliament of Georgia”, 25 November 2016, II, 8. 
FERNANDO, O. Conceptual Differences between the Civil Law System and the Common Law System. In Southwestern University Law Review. Vol.19, 1990.

GEGENAVA, D. Retrospection of the Constitutional Reforms of Georgia: In Search of the Holy Grail. In South Caucasus Law Journal, No.8 (2017).

GEGENAVA, D., JAVAKHISHVILI, P. Article 39 of the Constitution of Georgia: Internally Displaced Norm Pending the Shelter and the Phenomenon of Fear of the Unknown in Georgian Constitutionalism. In Academic Herald, Special Edition, 2017.

HART, H.L.A., Concept of Law, $2^{\text {nd }}$ Ed. Clarendon Law Series, 1997.

Institute for Development of Freedom of Information, Assessment of the Proposed Constitutional Amendments, 27 April 2017; available at <https://idfi.ge/en/evaluation_of_proposed_actions_as_part_of_georgias_constitution_project> [10/08/2018].

JACOBSOHN, G. J. Constitutional Identity. Harvard University Press, 2010.

JOWELL, J. Review of Amendments to the Constitution of Georgia in Respect of Human Rights and Judiciary Matters, March 2017.

KÜNNECKE, M. Tradition and Change in Administrative Law. An Anglo-German Comparison. Berlin : Springer, 2007.

LENY, L.W. Origins of the Bill of Rights. New Haven, London : Yale University Press, 2001.

MCAFFEE, T.B., BYBEE, J.S., BRYANT, A.C. Powers Reserved for the People and the States: A History of the Ninth and Tenth Amendments, A Reference Guide to the United States Constitution. Westport, Connecticut, London : Praeger Publishers, 2006.

PUTKARADZE, N. Human Rights in the Constitution of 21 February of 1921. In Beginnings of Georgian Constitutionalism - 90 Years of the Constitution of 1921. Batumi, 2011.

TUGHUSHI, T., BURJANADZE, G., MSHVENIERADZE, G., GOTSIRIDZE, G., MENABDE, V. Human Rights and Case-Law of the Constitutional Court of Georgia. Tbilisi, 2013.

ZOIDZE, B. Constitutional Control and Order of Values in Georgia. Tbilisi, 2007.

Basic Law of the Federal Republic of Germany, 23 May 1949.

Constitution of Georgia, 24 August 1995.

Constitution of the Democratic Republic of Georgia, 21 February 1921.

Constitutional Law on "Amending Constitution of Georgia”, 13 October 2017.

Constitutional Law on "Amending Constitutional Law on Amending Constitution of Georgia”, 23 March 2018.

General Administrative Code of Georgia, 25 June 1999.

Civil Code of Georgia, 26 June 1997.

Explanatory Note on the Draft Constitutional Law on "Amendment to the Constitution of Georgia"; available at: $<$ http://constitution.parliament.ge/uploads/masalebi/2. 05. konstitucia-barati.pdf> [06. 07. 2018].

Judgment \#1/7/727 of the Constitutional Court of Georgia on “Citizen of Georgia Giorgi Sekhniashvili v. Parliament of Georgia”, 21 April 2017.

Judgment \#1/9/664 of the Constitutional Court of Georgia on "Non-Profitmaking Organization "Open Circle of Georgia” v. Parliament of Georgia”, 25 November 2016.

Opinion on the Draft Constitutional Amendments Adopted on 15 December 2017 at the Second Reading by Parliament of Georgia, Adopted by the Venice Commission, CDL-AD (2018) 005, Venice, 16 - 17 March 2018.

Opinion on the Draft Revised Constitution Adopted by the Parliament of Georgia at the Second Reading on 23 June 2017, Adopted by the Venice Commission, CDL-AD (2017) 023, Venice, 6 - 7 October 2017.

Recording Notice \#2/2/416 of the Constitutional Court of Georgia on "Public Defender of Georgia v. Parliament of Georgia”, 29 May 2007.

Vallianatos and Others v. Greece. [ECtHR], App. nos. 29381/09 and 32684/09, 7 November 2013. 


\section{Contact Information:}

Associate Professor Dr. Dimitry Gegenava, Ph.D.

d.gegenava@sabauni.edu.ge

Sulkhan-Saba Orbeliani University

3, K. Kutateladze Str

0186

Tbilisi

Georgia 